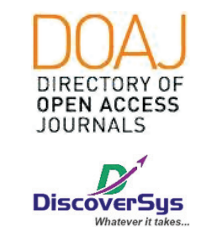

Published by DiscoverSys

\section{Faktor-faktor risiko yang berperan terhadap terjadinya infeksi luka operasi pada pasien post appendectomy di RSUP Sanglah Denpasar}

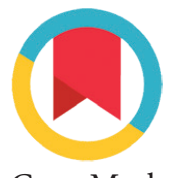

CrossMark

\author{
Danny Zefanya Mooy, ${ }^{1 *}$ I Gede Suwedagatha, ${ }^{2}$ Nyoman Golden ${ }^{3}$
}

\section{ABSTRACT}

Background: Surgical wound infection (SWI) is one of the three most common hospital-acquired infections, with an average of $14-16 \%$ and which is the most common infection in postoperative patients. This study aims to look for factors associated with post-operative wound infection in the appendectomy procedure at Sanglah General Hospital Denpasar. Methods: This study used a retrospective cohort design, which was carried out at the Medical Record Installation Sanglah General Hospital Denpasar, Bali-Indonesia during the January 2017 to September 2018. Data analysis used chi-square tests, relative risk calculations, and logistic regression.

Results: This study used 108 respondents, and there were 17 people who experienced SWI, the final analysis using logistic regression showed a diagnosis of perforated appendicitis (RR: 9.57; 95\% Cl: $2.09-43.64 ; p=0.004)$ and operator guidance resident (RR: 1.75 ; $95 \%$ Cl: $1.49-22.3 ; p=0.011)$ is a risk factor for the occurrence of the SWI.

Conclusion: The diagnosis of perforated appendicitis is the most important factor in the occurrence of surgical wound infection after appendectomy.
1PPDS-1 IImu Bedah, Fakultas Kedokteran, Universitas UdayanaRSUP Sanglah Denpasar, BaliIndonesia

${ }^{2}$ Divisi Bedah Trauma, Departemen/KSM IImu Bedah, Fakultas Kedokteran, Universitas Udayana-RSUP Sanglah Denpasar, Bali-Indonesia

3Departemen Bedah Saraf, Fakultas Kedokteran, Universitas Udayana-RSUP Sanglah Denpasar, Bali-Indonesia

\section{${ }^{*}$ Correspondence to:}

Danny Zefanya Mooy, PPDS-1

Ilmu Bedah, Fakultas Kedokteran, Universitas Udayana-RSUP Sanglah Denpasar, Bali-Indonesia dr.dannymooy@gmail.com

Diterima: $17-02-2020$

Disetujui: $30-06-2020$

Diterbitkan: 11-07-2020

Keywords: infection, risk factors, characteristics, surgery.

Cite This Article: Mooy, D.Z., Suwedagatha, I.G., Golden, N. 2020. Faktor-faktor risiko yang berperan terhadap terjadinya infeksi luka operasi pada pasien post appendectomy di RSUP Sanglah Denpasar. Intisari Sains Medis 11(2): 439-444. D0I: 10.15562/ism.v11i2.714

\title{
ABSTRAK
}

Latar Belakang: Infeksi luka operasi (IL0) merupakan salah satu dari tiga infeksi tersering yang didapat di rumah sakit, dengan rata-rata mencapai $14-16 \%$ dan yang merupakan infeksi yang paling sering terjadi pada pasien pasca operasi. Penelitian ini bertujuan untuk mencari faktor-faktor yang berhubungan dengan infeksi luka operasi pasca prosedur appendectomy di RSUP Sanglah Denpasar.

Metode: Penelitian ini menggunakan rancangan kohort retrospektif, yang dilakukan di Instalasi Rekam Medis RSUP Sanglah Denpasar, Bali-Indonesia selama periode Januari 2017 hingga September 2018.
Analisis data menggunakan uji chi-square, perhitungan risiko relatif, dan regresi logistik.

Hasil: Penelitian ini menggunakan 108 responden, dan terdapat 17 orang yang mengalami ILO, analisis akhir menggunakan regresi logistik menunjukkan diagnosis appendisitis perforasi (RR: 9,57; IK 95\%: 2,09-43,64; $p=0,004$ ) dan operator residen bimbingan (RR: 1,75; IK 95\%: $1,49-22,3 ; p=0,011$ ) merupakan faktor risiko terjadinya ILO.

Simpulan: Diagnosis appendisitis perforasi merupakan faktor yang paling berperan terhadap terjadinya infeksi luka operasi pasca appendectomy.

Kata kunci: infeksi, faktor risiko, karakteristik, operasi.

Cite Pasal Ini: Mooy, D.Z., Suwedagatha, I.G., Golden, N. 2020. Faktor-faktor risiko yang berperan terhadap terjadinya infeksi luka operasi pada pasien post appendectomy di RSUP Sanglah Denpasar. Intisari Sains Medis 11(2): 439-444. D0I: 10.15562/ism.v11i2.714

\section{PENDAHULUAN}

Infeksi luka operasi (ILO) merupakan salah satu dari tiga infeksi tersering yang didapat di rumah sakit, dengan rata-rata mencapai $14-16 \%$ dan yang merupakan infeksi yang paling sering terjadi pada pasien post operasi. Hampir dua pertiga angka kejadian ILO terbatas pada luka insisi operasi dan hanya sepertiga yang juga melibatkan organ atau bagian anatomi lain yang terlibat saat operasi. ILO juga sering terjadi setelah operasi appendectomy terutama pada appendisitis yang kompleks (gangrenosa dan rupture) dengan angka kejadian mencapai 9-53\%. Dimana dengan komplikasi ILO tentu akan menambah nyeri, waktu tinggal di rumah sakit dan biaya. Di Rumah Sakit Sanglah sendiri belum ada penelitian yang meunujukan angka kejadian ILO post appendectomy, maupun faktor risiko terjadinya ILO.

Banyak faktor risiko yang dapat mengakibatkan terjadinya infeksi luka operasi pada pasien 
post appendectomy, dan bisa diklasifikasi menjadi faktor pasien (komorbid, jenis appendicitis), faktor operasi(lama waktu operasi, operator), dan faktor kuman (jenis antibiotik yang digunakan). Jenis appendicitis yang komplikasi (gangrene dan rupture) merupakan faktor yang paling berperan dalam terjadinya ILO post appendectomy.

Penelitian yang dilakukan Louise $\mathrm{dkk}$, dari 637 pasien yang menjalani apendectomy ada 42 pasien $(6,6 \%)$ yang mengalami ILO dengan faktor risiko jenis appendisitis yang kompleks menjadi faktor utama. ${ }^{1}$

Noorit dkk, dari 607 pasien yang menjalani appendectomy ada 52 pasien yang terkena ILO tetapi tidak dijelaskan secara spesifik faktor apa yang mengakibatkan terjadinya ILO. ${ }^{2}$ Foster dkk, melakukan systematic review pada 423 abstracts didapat 35 studies yang masuk kriteria untuk qualitative dan quantitative, dengan hasil rata-rata angka kejadian ILO mencapai 17,9/100 open appendectomy dan 8,8/ 100 laparascopic appendectomy, dengan faktor risiko jenis apendisitis dan jenis antibiotik preoperative yang tidak adequate. ${ }^{3}$

Leong dkk, melakukan penelitian tentang $T$ times pada operasi berpengaruh terhadap angka kejadian ILO, dengan kesimpulan pasien yang dioperasi lebih lama dari $T$ times nya memiliki risiko yang besar terjadinya ILO pada hamper semua kategori operasi. ${ }^{4}$

Berdasarkan Guidline World Health Organization (WHO) tentang ILO, salah satu faktor yang berpengaruh terhadap angka kejadian adalah factor operator dimana berpengaruh dalan hal teknik operasi dan tissue handling, meskipun factor risiko ini masih tergolong kecil di bandingkan dengan factor risiko lain yang menyebabkan ILO. ${ }^{5}$

Dari pemaparan di atas dapat ditarik kesimpulan bahwa angka kejadian ILO pada pasien post appendectomy berhubungan atau dipengaruhi dengan banyak faktor, pada penelitian ini penulis mencoba mencari apakah Angka kejadian ILO pada pasien post appendectomy berhubungan dengan jenis appendicitis, lama waktu operasi, dan operator yang mengerjakan yang digunakan.

\section{METODE}

Penelitian ini menggunakan rancangan kohort retrospektif, dilakukan di instalasi rekam medis RSUP Sanglah Denpasar selama periode bulan Januari 2017 sampai September 2018. Sampel dalam penelitian ini adalah pasien appendsitis akut yang menjalani operasi appendectomy di RSUP Sanglah Denpasar. Kriteria inklusi dalam penelitian ini adalah rekam medis yang lengkap dan mencantumkan outcome adanya ILO atau tidak dengan catatan kontrol pasca operasi. Kriteria eksklusi adalah rekam medis tidak lengkap atau penderita meninggal dunia. Analisis data dalam penelitian ini menggunakan bantuan program SPSS versi 25.0 untuk Windows. Uji cho-square disertai dengan perhitungan risiko relative untuk mencari hubungan faktor-faktor yang berhubungan terhadap ILO pasca operasi appendectomy serta uji regresi logistic digunakan untuk mencari fakto yang paling berperan terhadap terjadinya ILO pasca appendectomy. Seluruh nilai dianggap bermakna apabila nilai $\mathrm{p}<0,05$.

\section{HASIL}

Penelitian ini melibatkan 108 responden secara restrospektif dengan sumber data yang berasal dari rekam medis responden, karakteristik sampel penelitian dapat dilihat pada tabel 1 .

Tabel 1 menunjukkan kategori umur dalam penelitian didapatkan nilai rata-rata (mean) 30 dengan SD:13,9. Kategori umur terbanyak pada kelompok umur $\leq 30$ tahun yaitu 67 responden (62\%). Karakteristik berdasarkan jenis kelamin didapatkan laki-laki dengan perempuan hampir seimbang dimana laki-laki sebanyak 55 responden $(50,9 \%)$ dan perempuan sebanyak 53 responden $(49,1 \%)$. Karakteristik berdasarkan diagnosis appendisitis didapatkan appendisitis perforasi sebanyak 48 responden $(44,4 \%)$ dan appendisitis non perforasi sebanyak 60 resonden $(55,6 \%)$. Karakteristik berdasarkan lama waktu operasi dengan kategori $\geq 90$ menit sebanyak 60 responden $(55,6 \%)$ dan $<90$ menit sebanyak 48 responden $(44,4 \%)$. Karakteristik berdasarkan operator operasi dibagi menjadi residen bimbingan sebanyak 60 responden $(55,6 \%)$ dan dikerjakan oleh senior sebanyak 48 responden $(44,4 \%)$.

Data appendisitis perforasi yang terjadi ILO sebanyak 14 responden $(82,3 \%)$ dan yang tidak terjadi ILO 34 responden (37,3\%) sedangkan appendisitis non perforasi didapatkan dengan jumlah yang lebih sedikit terjadi ILO yaitu 3 responden (17,7\%) dan tidak terjadi ILO 57 responden $(62,7 \%)$. Nilai RR menunjukka angka RR 5,8 (IK: 1,77-19,13) yang berarti pasien dengan diagnosis apendiks perforasi memiliki risik 5,8 kali lebih besar untuk mengalami ILO dibandingkan dengan pasien dengan diagnosis appendicitis. Ditemukan adanya hubungan yang bermakna antara diagnosis appendicitis terhadap infeksi luka operasi $(\mathrm{p}=0,001)$ (Tabel 2$)$.

Data lama operasi $\geq 90$ menit yang terjadi ILO sebanyak 14 responden $(82,3 \%)$ dan yang tidak terjadi ILO 46 responden (50,5\%) sedangkan lama operasi $<90$ menit didapatkan dengan jumlah yang lebih sedikit terjadi ILO yaitu 3 responden $(17,7 \%)$ dan tidak terjadi ILO 45 responden 
Tabel 1 Karakteristik responden penelitian

\begin{tabular}{ll}
\hline Variabel & $\mathbf{n = 1 0 8}$ \\
\hline Umur (Rerata \pm SD) & $30 \pm 13,9$ \\
$>30$ & $41(38 \%)$ \\
$\leq 30$ & $67(62 \%)$ \\
Jenis kelamin (n,\%) & \\
$\quad$ Laki-laki & $55(50,9 \%)$ \\
Perempuan & $53(49,1 \%)$ \\
Diagnosis (n,\%) & \\
Appendisitis perforasi & $48(44,4 \%)$ \\
Appendisitis non perforasi & $60(55,6 \%)$ \\
Lama operasi (n,\%) & \\
$\geq 90$ menit & $60(55,6 \%)$ \\
$<90$ menit & $48(44,4 \%)$ \\
Operator tindakan (n,\%) & \\
Residen bimbingan & \\
Senior & $60(55,6 \%)$ \\
\hline
\end{tabular}

Tabel 2 Hubungan umur jenis kelamin appendisitis perforasi, lama operasi dan operator operasi dengan infeksi luka operasi

\begin{tabular}{|c|c|c|c|c|c|}
\hline \multirow[b]{2}{*}{ Variabel } & \multicolumn{2}{|c|}{ Infeksi luka operasi } & \multirow[b]{2}{*}{$\mathbf{R} \mathbf{R}$} & \multirow[b]{2}{*}{ IK 95\% } & \multirow[b]{2}{*}{$\mathbf{p}$} \\
\hline & Ada ILO & Tidak ada ILO & & & \\
\hline \multicolumn{6}{|l|}{ Umur (tahun) } \\
\hline$>30$ tahun & $7(41,2 \%)$ & $34(37,4 \%)$ & 1,1 & $0,47-2,77$ & 0,766 \\
\hline$\leq 30$ tahun & $10(58,8 \%)$ & $57(62,6 \%)$ & & & \\
\hline \multicolumn{6}{|l|}{ Jenis kelamin } \\
\hline Laki-laki & $9(52,9 \%)$ & $46(50,5 \%)$ & 1 & $0,45-2,59$ & 0,856 \\
\hline Perempuan & $8(47,1 \%)$ & $45(49,5 \%)$ & & & \\
\hline \multicolumn{6}{|l|}{ Diagnosis appendisitis } \\
\hline Appendisitis perforasi & $14(82,3 \%)$ & $34(37,3 \%)$ & 5,8 & $1,77-19,13$ & 0,001 \\
\hline Appendisitis non perforasi & $3(17,7 \%)$ & $57(62,7 \%)$ & & & \\
\hline \multicolumn{6}{|l|}{ Lama operasi (menit) } \\
\hline$\geq 90$ menit & $14(82,3 \%)$ & $46(50,5 \%)$ & 3,7 & $1,13-12,24$ & 0,015 \\
\hline$<90$ menit & $3(17,7 \%)$ & $45(49,5 \%)$ & & & \\
\hline \multicolumn{6}{|l|}{ Operator operasi } \\
\hline Residen bimbingan & $13(76,4 \%)$ & $47(51,6 \%)$ & 2,6 & $0,90-7,46$ & 0,059 \\
\hline Senior & $4(23,6 \%)$ & $44(48,4 \%)$ & & & \\
\hline
\end{tabular}

Tabel 3 Pengaruh diagnosis appendisitis lama operasi dan operator tindakan dikontrol dengan variabel umur dan jenis kelamin terhadap infeksi luka operasi

\begin{tabular}{lccccc}
\hline Variabel & B & SE & Exp (B) & IK 95\% & p \\
\hline Umur & 0,12 & 0,64 & 1,13 & $0,31-4,05$ & 0,844 \\
Jenis kelamin & 0,34 & 0,64 & 1,40 & $0,40-4,94$ & 0,593 \\
Diagnosis appendisitis perforasi & 2,25 & 0,77 & 9,57 & $2,09-43,64$ & 0,004 \\
Lama operasi $\geq 90$ menit & 0,60 & 0,78 & 1,82 & $0,39-8,51$ & 0,446 \\
Operator tindakan residen bimbingan & 1,75 & 0,69 & 5,77 & $1,49-22,3$ & 0,011 \\
\hline
\end{tabular}


(49,5\%). Nilai RR menunjukkan nilai 3,7 (IK: 1,1312,24) memiliki makna bahwa durasi operasi lebih dari 90 menit memiliki risiko 3,7 kali lebih besar untuk mengalami infeksi luka operasi dibandingkan dengan durasi operasi kurang dari 90 menit. Serta diteukan adanya hubungan yang signifikan antara durasi operasi terhadap infeksi luka operasi $(\mathrm{p}=0,015)$. Sedangkan variabel usia, jenis kelamin, dan operator operasi tidak memiliki hubungan yang bermakna terhadap ILO pasca appendectomy (Tabel 2).

Variabel diagnosis appendisitis dan operator tindakan dengan $\mathrm{p}$-value $<0,05$ yang berarti diagnosis appendisitis perforasi dan operator tindakan operasi mempunyai pengaruh parsial terhadap terjadinya ILO. Diagnosis appendisitis didapatkan dengan nilai B positif yang berarti ada hubungan yang positif dari diagnosis appendisitis dengan terjadinya ILO dengan nilai OR 9,57 berarti diagnosis appendisitis perforasi memiliki risiko 9,75 kali lebih besar untuk terjadinya ILO dibandingkan dengan. Operator tindakan oleh residen bimbingan didapatkan dengan nilai OR 5,77 berarti operator tindakan oleh residen bimbingan memberikan risiko untuk terjadinya ILO 5,77 kali lebih besar dibandingkan dengan operator yang dikerjakan oleh residen senior. Hal ini dapat disimpulkan faktor risiko yang paling dominan menyebabkan infeksi luka operasi adalah appendisitis perforasi (Tabel 3).

\section{PEMBAHASAN}

Infeksi Luka Operasi (ILO) merupakan salah satu dari tiga infeksi tersering yang didapat di rumah sakit, dengan rata-rata mencapai $14-16 \%$ dan yang merupakan infeksi yang paling sering terjadi pada pasien post operasi. Hampir dua pertiga angka kejadian ILO terbatas pada luka insisi operasi dan hanya sepertiga yang juga melibatkan organ atau bagian anatomi lain yang terlibat saat operasi. ILO juga sering terjadi setelah operasi appendectomy terutama pada appendisitis yang kompleks (gangrenosa dan rupture) dengan angka kejadian mencapai 9-53\%. Dimana dengan komplikasi ILO tentu akan menambah nyeri, waktu tinggal di rumah sakit dan biaya., ${ }^{2,6}$ Berbagai faktor risiko seperti jenis appendicitis, lama waktu operasi, alat dan ruang operasi, operator yang mengerjakan, maupun kondisi pasien yang di operasi juga ikut berkontribusi untuk terjadinya ILO, ${ }^{2,5}$ Jenis insisi dalam prosedur appendicitis tidak memberikan adanya perbedaan terhadap ILO, hal ini didukung oleh penelitian yang dilakukan oleh Ozsan dkk (2014) yang menemukan tidak terdapat perbedaan antara komplikasi ILO antara penggunaan laparoskopik appendektomi yang dibandingkan dengan insisi konvensional appedektomi 71 orang pasien $(\mathrm{p}=0,89)^{7}$

Faktor risiko yang dievaluasi pada penelitian ini adalah jenis appendicitis, lama waktu operasi, dan operator yang mengerjakan operasi. Dalam penelitian ini didapatkan jenis appendicitis, lama waktu operasi dan operator yang mengerjakan merupakan faktor risiko terjadinya ILO pada pasiern post appendectomy. Setelah dilakukan uji regresi logistic, didapatkan bahwa jenis appendicitis merupakan faktor utama terjadinya ILO pada pasien post appendectomy.

Pada penelitian ini, dari uji bivariate dan uji regresi logistik, jenis appendicitis merupakan faktor risiko utama terhadap terjadinya ILO pada pasien post appendectomy. Hali ini didukung oleh penelitian lain yang menyatakan jenis appendicitis merupakan faktor utama terjadinya ILO pada pasien post appendectomy. ${ }^{3,8}$ Dari penelitian yang dilakukan oleh Giesen dkk (2016) dari 637 pasien yang masuk kriteria penelitian, 42 pasien dengan ILO, dengan appndisitis perforasi (kompleks) secara signifikan berkaitan dengan infeksi luka operasi pada pasien post appendectomy (OR 4,09;95\% IK 2.04-8.20), dan juga penelitian ini menyatakan penutupan luka operasi dengan alat stepler juga berkorelasi dengan infeksi luka operasi pada pasien post appendectomy, meskipun hal ini tidak diteliti dalam penelitian ini. ${ }^{9}$ Penelitian yang dilakukan oleh Foster dkk (2017), meneliti tentang Infeksi luka operasi yang terjadi pada pasien appendicitis yang dilakukan tindakan operasi open appendectomy di bandingkan dengan tindakan laparaskopi, dimana di dapatkan hasil rata-rata 17,9 infeksi/100 operasi open appendectomy dan 8,8 infeksi/100 laparaskopi appendectomy, dengan angka kejadian ILO tertinggi pada pasien dengan appendicitis perforasi (kompleks). Dalam penelitian ini juga menyebutkan penggunaan antibiotic profilaksis yang tidak adekuat juga merupakan factor risiko terjadinya infeksi luka operasi. $^{3}$

Dari uji bivariate dan multivariate lama waktu operasi merupakan faktor risiko terjadinya ILO dalam penelitian ini. Temuan ini sesuai dengan penelitian yang dilakukan oleh Leong dkk (2006), dimana waktu opersi yang lebih dari $T$ times (merupakan batasan waktu yang ditetapkan peneliti untuk menentukan durasi operasi lama atau pendek) sangant berkorelasi dengan angka kejadian infeksi luka operasi. ${ }^{4}$ Pada penelitian ini memang tidak spesifik pada pasien appendisitis, tapai pada semua jenis operasi. Sama dengan penelitian yang dilakukan oleh Noorit dkk (2018), dimana dari 607 pasien yang diteliti didapatkan $8,7 \%$ infeksi 
luka operasi pada pasien post appnedisitis, dengan empat faktor risiko: diabetes mellitus, insisi luka operasi lebih dari $7 \mathrm{~cm}$, kontaminasi fekal, dan lama waktu operasi lebih dari 75 menit, yang secara signifikan berpengaruh terhadap terjadinya infeksi luka operasi pada psien post appendisitis. ${ }^{2}$ Penelitian ini menggunakan batasan 90 menit oleh karena rerta waltu operasi dalam penelitian ini adalah 92,88 $\pm 22,15$ menit, sehingga diambil suatu nilai batas 90 menit sebagai acuan untuk penentu durasi operasi yang lebih lama dan lebih pendek.

Dari uji analisis bivariate penelitian ini didapatkan operator operasi residen bimbingan merupakan faktor risiko terjadinya infeksi luka operasi pada pasien post appendectomy, meskipun tidak secara signifikan berkorelasi (nilai $\mathrm{p}=0,059$ ), tetapi didapatkan dengan nilai RR 2,6 (IK: 0,90$7,46)$ berarti operator operasi dapat meningkatkan terjadinya ILO. Dalam penelitian ini residen yang dimaksudkan bimbingan yang dimaksudkan adalah residen jaga 2 kebawah, sedangkan senior adalah residen jaga 2 keatas. Memang sampai sekarang peneliti belum menemukan ada yang meneliti mengenai faktor risiko operator yang berkaitan dengan infeksi luka operasi pada psien post appendectomy atau operasi yang lain, tetapi dalam guidline terbaru dari WHO, 2016 mengenai pencegahan infeksi luka operasi disebutkan operator operasi juga merupakan salah satu factor risiko terjadinya infeski luka operasi diaman sangat berkaitan dengan teknik operasi yang dilakukan, tissue handling, higienitas operator atau yang terlibat dalam operasi sangat berkaitan dengan timbulnya infeksi luka operasi. ${ }^{5}$

Keterbatasan dalam penelitian ini adalah Penelitian ini menggunakan rancangan retrospektif yang hanya bersumber dari data rekam medis, hal ini menyebabkan nilai kebermaknaa risiko jauh lebih rendah dibandingkan dengan penelitian kohort prospektif, disampng itu data yang bersumber dari rekam medis terkadang tidak sepenuhnya lengkap mengenai faktor-faktor risiko yang dialami sehingga hal ini juga memberikan kendala dalam pengumpulan sampel dalam penelitian. Kelemahan pada penelitian ini adalah banyaknya operator yang mengerjakan operasi appendectomy sehingga peneliti hanya bisa membagi menjadi operator residen bimbingan dan operator senior, sehingga dirasakan kurang spesifik. Penelitian ini juga belum menilai adanya faktor - faktor lain yang dapat mempengaruhi kejadian infeksi luka operasi pada pasien post appendectomy. Selanjutnya hal lain yang juga ikut berkontribusi adalah kepatuhan pasien dalam kontrol pasca operasi, sehingga hal ini menjadi sesuatu yang turut berkontribusi terhadap terjadinya ILO.

\section{SIMPULAN}

Pada penelitian ini didapatkan satu variable yang murni menjadi faktor risiko terjadinya infeksi luka operasi pada pasien pasca appendectomy yaitu jenis appendicitis yang diapatkan durante operasi. Operator operasi residen bimbingan merupakan faktor risiko terjadinya infeksi luka operasi pada pasien post appendectomy, meskipun tidak secara signifikan berkorelasi ( $\mathrm{p}$-value $0,059>0,05$ ), tetapi didapatkan dengan nilai RR 2,6> 1 (IK: 0,90-7,46) berarti operator operasi dapat meningkatkan terjadinya ILO.

\section{SARAN}

Perlu dilakukan penelitian lebih lanjut untuk menilai faktor - faktor lain yang mempengaruhi terjadinya infeksi luka operasi pada pasien post appendectomy: seperti jenis antibiotic profilaksis, lebar luka insisi,dan faktor comorbid pada pasien. Atau pun penelitian tentang strategi khusus untuk pencegahan terjadinya infeksi luka operasi. Pada saat melakukan bimbingan operasi, residen senior harus menuntun residen bimbingan dengan seksama, memperhatikan aspek higenitas, antisptik, tissue handling, dan durasi operasi, sehingga kecendrungan untuk ILO ketika melakukan operasi bimbingan menjadi lebih kecil.

\section{KONFLIK KEPENTIGAN}

Peneliti menyatakan tidak terdapat suatu konflik kepentingan terkait publikasi dari penelitian ini.

\section{PENDANAAN}

Penelitian ini tidak mendapatkan hibah dana dari pemerintah ataupun sector swasta lainnya.

\section{ETIKA DALAM PUBLIKASI}

Penelitian ini telah mendapatkan persetujuan dari Komite Eti Fakultas Kedokteran, Universitas Udayana/RSUP Saglah Denpasar dengan nomer referensi kelayakan etik 38/UN14.2.2.VII.14/ LP/2019.

\section{DAFTAR PUSTAKA}

1. Louis JXG. Anne LVB, dkk. Retrospective Multicenter Study on risk Factor for Surgical Site Infection after Appendectomy for Acute Appendicitis. Dig Surg. 2016;34(2)::103-107.

2. Noorit P, Siribumrungwung B, Thakkinstian A. Clinical prediction score for superficial surgical site infection after appendectomy in adults with complicated appendicitis. World J Emerg Surg. 2018;13:1-7. 
3. Foster D, Kethman W, Weiser TG, Cai LZ, Forrester JD. Surgical site infection after appendectomy performed in low and middle human development index countries: a systematic review. Surg Infect (Larchmt). 2018;19(3):237-244.

4. Leong G, Wilson J, Charlett A. Duration of operation as a risk factor for surgical site infection: comparation of English and US data. Journal of Hospital Infection. 2006;63: 255-262.

5. World Health Organization. Global Guidelines for the prevention of surgical site infection; 2016.

6. Tiono B, Sudartana K, Widiana R. There is no difference of surgical site infection between single-dose and multiple-dose of prophylaxis antibiotic in open appendectomy of non-perforated acute appendicitis. Bali Medical Journal. 2012;1(3):121-124.

7. Ozsan I, Karabuga T, Yoldas O, Alpdogan O, Aydin U. Laparoscopic appendectomy versus mini-insicion appendectomy in patients with lower body mass index and noncomlicated appendicitis. Gastroenterology Research and Practice. 2014;2014:1-4.
8. Gaynes RP, Culver DH, Horan TC, Edwards JR, Richards C, Tolson JS. Surgical Site Infection (SSI) Rates in the United States, 1992-1998: The National Nosocomial Infections Surveillance System Basic SSI Risk Index. Clinical Infectious Diseases. 2001;33:S69-S77.

9. Giesen LJ, van den Boom AL, van Rossem CC, den Hoed PT, Wijnhoven BP. Retrospective multicenter study on risk factors for surgical site infection after appendectomy for acute appendicitis. Dig Surg. 2017;34(2):103-107.

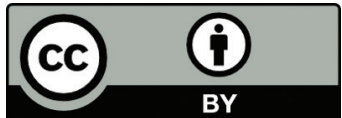

This work is licensed under a Creative Commons Attribution 